\title{
English Summary of Chapter 4
}

\author{
Stefan Reichmuth
}

Since the inception of the "Syndicate of the Descendants of the Prophet" (niqābat al-ashrāf) in the tenth century, this institution was considered as a part of what the Muslim jurists called the "(public) institutions provided by (Islamic) law" (al-wilāyāt al-shar'iyya), that is, the political, administrative, and social institutions of the Islamic state, such as the police, market supervision (hisba), judiciary, and the administration of religious endowments. It thus belonged to the institutions which fell under the final authority of the caliph. Whenever the Islamic heritage gained in importance for the caliphate, the hisba, and the judiciary, these institutions became the subject of meticulous reflection, independent jurisprudence, and of a rich literary production. Other institutions were rather neglected, and reflection about them did only sparsely develop; even though they were equally essential to Islamic society, such as the police and the Syndicate of the Descendants of the Prophet.

With respect to the niqābat al-ashrāf, we observe that reflection on it was rather developed by Shāfíi jurists than by the other schools of law, which for a long time shared the conceptual framework that had been developed by the Shāfi'is. The most influential legal treatise discussing this topic was the famous book written by Abū l-Hasan al-Māwardī (d. 45o/1058), "The Legal Provisions of Rule and of the Islamic Public Institutions" (al-Ahkām al-sultāniyya wa-l-wilāyāt al-islāmiyya), where the legal framework of the niqābat al-ashrāf is laid out in chapter 8. The contemporary Hanbalī jurist Abū Ya'lā al-Farrā' (d. 458/1066) shows a close resemblance to Māwardī's text in his own al-Aḥkām al-sultāniyya. Both works seems to represent the legal consensus which was apparently shared during their time by the different legal schools.

According to Māwardī, the basic principle on which the niqāba is founded is the protection of those of noble ancestry from the power of those who do not equal them by descent and nobility. In the fifth Islamic century, Muslim society viewed the descendants of the Prophet either with great esteem (in the case of the Sunnīs), or with outright veneration (in the case of the Shīiss), conceding to them the right of institutional independence from any external authority. Māwardī did not find an outright legal proof for this independence and for the establishment of a syndicate; but he referred to a Prophetic hadith which called in general terms for the knowledge of one's ancestry and for the loyalty towards one's relatives. He established his concept of institutional independence without bothering about any further proof, and connected the 
notion of the niqāba with the concept of the authority of the ruler (al-wilaya al-sultāaniyya), from which it depends like the other public authorities. This implies its independence from the interference of the people in general, but not from the caliph from whom its authority is derived, or from his delegated representatives. Its legitimacy thus depends on the power and legitimacy of the caliphate.

In accordance with the development of the position of the ashräf after the emergence of the 'Abbāsids, the Fāțimids, and the Idrīsids, Māwardī distinguishes between a "special niqāba" (niqāba khāsșa) with political and supervisory functions, and a "general niqua ba" (niqāba 'āmma) to which legal functions are also added. He defines twelve duties for the first one, which are related to the preservation of Sharifian descendance, of morals and discipline, and of social cohesion, supervision, and finances. This gave the niqāba an autonomous status within the state and made it a political office. The naqib was to be appointed from the group of the ashräf on the basis of his personal qualities and merits. Legal knowledge, however, was not among the preconditions of this office in the case of the "special niqāba", in contrast to the "general" one, where the legal authority of a $q \bar{a} d \bar{\imath}$ was added to its political functions, which required legal competence.

Under Mamlūk rule the importance of the niqābat al-ashrāf seems to have diminished, as can be gleaned from its treatment by Qalqashandī (d. 821/1418) in his Șubh al-ashā, where he mentions that the holder of this office has no direct political responsibility vis-à-vis the sultan and is therefore not included in the council of the ruler. It is reckoned by him under the religious offices, and he mentions both genealogical and supervisory functions for it. He states that it had become established custom that the naqib should be appointed from the leaders of the ashräf (ru'üs al-ashräf) and that he belong to the scribal class (arbāb al-aqlām). The principles otherwise laid down by Māwardī seem to have been generally respected in the course of Islamic history.

Although the scholars of the Maghrib were familiar with the office of the niqāba as it existed in the Orient, they do not hint at its existence in their region, and they apparently considered it to be an Eastern innovation that had no basis in the sharī ${ }^{-}$. This position is expressed by the Mālikī $q \bar{a} d \grave{\imath}$ of Seville, Abū Bakr b. al-'Arabī (d. 543/1148), who had travelled widely in the 'Abbāsid and Fāțimid realms. Ibn Khaldūn (d. 808/1405) only mentions it in passing in the context of the offices connected with the caliphate, which for him had become obsolete along with the caliphate itself. That he does not consider its existence either in the East or in the West is evident from his failure to mention it at all, apart from this passing remark, and also from his neglect of the science of genealogy as part of both figh and history, which is lacking in his otherwise 
ample description of the sciences of his time. On the other hand, he staunchly defends the Idrīsids and their authentic descent from the Prophet.

The books on the "counsel of kings" (ādāb al-mulūk) which were written in the Maghrib and in Andalus during that period also largely ignore the institution of the niqa $\bar{a} a$, an impression which can be gained from the anonymous work al-Risāla al-wajizza ilā al-ḥadra al-'azizziyya fi ulüm al-khiläfa, and from Ibn Riḍwān al-Māliqī (d. 783/1381), al-Shuhub al-lāmía fì l-siyāsa al-nāfía, and, after Ibn Khaldūn, Abū 'Abd Allāh b. al-Azraq (d. 896/149o).

It can be noted that the juridical treatises of the Māliki jurists discussed the descendants of the Prophet mostly in the chapters on the zakāt, from which it can be seen that theoretical positions and social developments were at odds with each other. Ibn Juzayy al-Kalbī al-Gharnāțī (d. 741/1340), al-Qawānīn al-fighiyya, records a number of legal opinions with regard to the permissibility of zakāt or voluntary donations to the ahl al-bayt. Hațtāb (d. 954/1547) mentions in his Mawāhib al-jalïl (a commentary to Khalīl b. Isḥāq's Mukhtaṣar) the old negative view which had formerly prevailed in Mālikī law, and which was giving way to a new one which allowed such donations. It was built on the principle of necessity (darüra), as the descendants of the Prophet had become in danger of losing their income after the neglect of their needs by the caliphs and by the decline of the system of the bayt al-mäl. Under these conditions, a donation to the $a s h r a \bar{f}$, which should be given to them directly, thus had become an act rewarded by God.

References to the niqāba, which are lacking in the legal treatises of the Mālikì madhhab, can be found scattered across the genealogical and historical literature. Historians and genealogists like Muhammad b. al-Ṭayib al-Qādirī (d. 1187/1773) in his Nashr al-mathānī, or al-Ṭālib b. al-Hạajj (d. 1273/1856) in his al-Ishräf, more explicitly hint at the significance of the niqāba for the protection of the purity of the Prophetic descent, which according to them requires broad genealogical, historical, and codicological knowledge. The office should normally be held by a sharîf but could be given to a better qualified scholar of non-Sharifian descent if no sufficiently learned descendant of the Prophet was available. Holders of this office are occasionally mentioned, like the Jutụi family in Fez and their role in some of the crises and revolts in the period of the Marinid sultans. Others belonged to the ashräf of Jabal al-'Alam, or to Sharifian families from Sijilmāsa and elsewhere. It appears significant that the requirement of legal and historical knowledge is much stressed by Qādirī, and that the distinction between "special" and "general" niqāba has been abandoned in Maghribī practice. This then became the new legal position of the Mālikī school in Morocco. 
The period of the Marinid sultanate is described by legal scholars of the last five centuries who are also genealogists and historians as the golden age for the relations between the ashräf and the sultanate and between sultan and naqüb. Abū l-Qāsim al-Zayyānī (d. 1249/1833) is quoted with his Tuhfat al-hădì al-mutrib for a description of this glorious office since the days of the Umayyads and the 'Abbāsids and for its high rank in the Maghrib, which according to him lasted from the time of the Almoravids, Almohads, and Marinnids until the first Sadian sultans. It then fell into serious decline in the disturbances which arose after the death of Sultan Ahmad al-Manșūr (d. 1012/16o3). This led to widespread misappropriation and manipulation of the niqāba in the hands of unqualified holders without proper supervision, who for their own benefit awarded Sharîfian titles to claimants without proper verification of their claims.

This lamentable state of affairs, the first of the crises of the niqāba office in Morocco, only ended with the rise of the 'Alawì sultans to power. Zayyānī describes at length the revival and renewal of the niqāba by Mawlāy Ismāîl (1082-1139/1672-1727), who reorganised and thoroughly revised the Sharifian register after proper verification by qualified scholars and other knowledgeable people. He thus secured his leadership in the religious as well as in the worldly realms. He also appointed new nuqaba $\vec{a}^{3}$ in Fez, Meknes, Marrakesh, and Jabal al-'Alam, where the senior naqib came to reside. By these measures the office was firmly attached to the state apparatus (makhzan) of the 'Alawī court.

A second crisis of the niqāba set in after the death of Mawlāy Ismā'il, with growing misuses of its holders and the issuing of fake documents, which lasted until the rule of Mawlāy Muḥammad b. 'Abd Allāh (1171-1204/1759-9o). After receiving many complaints against the malpractice which had spread even to tribal areas, this sultan thoroughly revised the organisation of the office and of the registers, and he appointed office-holders who were paid by the state, without receiving any other gifts and payments. After a third crisis of the niqāba system during the short rule of his son Mawlāy Yazīd (d. 1206-1792), it was stabilised again under his successor, the scholar-sultan Mawlāy Sulaymān (1206-38/1792-1822). By then the three crises of the niqāba had led to the emergence of prominent genealogists and of a flourishing genealogical literature in Morocco.

It has become clear by this presentation of the history of the niqābat al-ashrāf in Morocco that the Mâliki jurists had been latecomers to this legal field, and had not contributed to its concept, which had been largely shaped by Mâwardī. It was only during the last centuries that they came to develop 
something like a legal framework for it. This, however, cannot be found either in their legal treatises or in the nawazzil literature but in the writings of the Mālikì historians and genealogists of the later centuries. These had to adapt the norms defined by Mâwardī to the cultural and historical realities of the Maghrib. It was these realities and their recurring crises which led to the emergence of discussions and writings on the concept and norms of the niqāba and on the history of this old institution in the Islamic West, especially in Morocco. 